\title{
INTRODUCTION
}

\section{Rethinking Climate Change, Conflict and Security}

\author{
JAN SELBY \\ Department of International Relations, University of Sussex, Brighton, UK \\ CLEMENS HOFFMANN \\ Department of International Relations, Bilkent University, Ankara, Turkey
}

\begin{abstract}
This special issue of Geopolitics presents a series of critical interventions on the links between global anthropogenic climate change, conflict and security. In this introduction, we situate the special issue by providing an assessment of the state of debate on climate security, and then by summarising the eight articles that follow. We observe, to start with, that contemporary climate security discourse is dominated by a problematic ensemble of policy-led framings and assumptions. And we submit that the contributions to this issue belp rethink this dominant discourse in two distinct ways, offering both a series of powerful critiques, plus new interpretations of climate-conflict linkages which extend beyond Malthusian orthodoxy.
\end{abstract}

\section{CLIMATE CHANGE AND SECURITY: THE STATE OF DEBATE}

Held amidst the neo-classical splendour of London's Lancaster House, the UK Foreign and Commonwealth Office's 2012 conference on climate and resource security brought together a couple of hundred diplomats, politicians, military officials, and corporate and NGO representatives to push forward the 'international debate' on climate security. The conference was opened by Ed Davey, UK Secretary of State for Climate Change and Energy, who characterised global climate change as a 'threat multiplier' that would

Address correspondence to Jan Selby, Department of International Relations, University of Sussex, Brighton BN1 9QN, UK. E-mail: j.selby@sussex.ac.uk 
magnify existing resource pressures, especially in 'fragile' states 'already under threat', and concluded that 'we need to be ready for a world where climate instability drives political instability'. ${ }^{1}$ Thereupon followed a series of gloom-ridden pronouncements - from President Ali Bongo Ondimba of Gabon's assertion that climate change in Africa 'will cause armed conflicts in 23 countries and political unrest in another 13' (by what exact date wasn't clear); to the claim that there are currently 350,000 climate-related deaths per year worldwide, rising to 1 million per year by 2030 if no action is taken. ${ }^{2}$ When one of the just two academics in attendance - who happened to be one of the present authors - had the temerity to comment from the floor that there was no scientific consensus on the conflict and security implications of climate change, the response was immediate and striking. One speaker dismissed this point as evidence of academic 'hubris'. Another dismissed it on the grounds that consensus is lacking on all manner of issues (which is of course true - but that hadn't stopped him or other participants from speaking as if there did exist a consensus on this particular subject). And still another asserted that the links between climate change and conflict were obvious, since $80 \%$ of conflicts happen in arid zones. Something close to a diplomatic norm had been violated.

We begin with this vignette because it nicely captures several key features of contemporary discourse on anthropogenic climate change, conflict and security. It illustrates, first, just how entrenched certain assumptions and narratives about climate security are, right across Western governments, militaries and civil society - as well as, if to a lesser degree, in academia. Most of this discourse is resolutely Malthusian, in both substance and tone. Thus on the one hand its overall tone is deeply pessimistic, foreseeing a future in which, to give but a brief selection of examples, there is large-scale environmental migration 'potentially involving hundreds of millions' or even 'perhaps billions of people' ${ }^{3}$; in which climate change will 'probably' be 'the biggest trigger of genocide in the twenty-first century'4; in which, by 2030 , an additional 393,000 African lives may be being lost each year through warming-induced conflict ${ }^{5}$; and in which, by 2037, there may be widespread social 'collapse', including of such things as 'the northern tier of African countries', 'liberal concepts of openness', 'multilateral institutions', 'financial and production systems', 'health care systems', and more besides. ${ }^{6}$ Such dystopian scenarios aside, most climate security discourse is also indebted to the Malthusian tradition for its core ontological and political premises. Its overwhelmingly environmentally determinist world-view ascribes causal primacy to environmental resources - and especially to presumed resource scarcities - in generating societal stress, breakdown and conflict. Moreover, just as Malthus identified the poor as the main social agents of resource crisis, so contemporary climate security discourse tends to interpret the global poor, and Sub-Saharan Africans in particular, as the most likely subjects and also sources - of climate-related conflict. As a corollary, climate security 
thinking tends to provide only the thinnest analysis of political and politicaleconomic structures and processes, including of the power and strategies of local elites and states, and of the international and global contexts in which these are embedded. Its primary concern with the conflict impacts of climatic changes - increased temperatures, shifting rainfall patterns, and so on - also results in a striking neglect of the possibility that climate change mitigation and adaptation measures might contribute (or may already be contributing) to conflict. In sum, most of this discourse is highly climate-centric, 'reducing the future to climate' and failing to adequately contextualise climate impacts in relation to broader processes of global and social change, even when it is acknowledged that these climate impacts will only ever occur in intersection with other threats and factors. ${ }^{7}$

The 'international debate' on climate security is also - as the Lancaster House conference made abundantly clear - led mostly by policy, military and NGO actors, not scientists. In this, the climate security field diverges sharply from other areas of climate change policy, where scientists have played formative, if far from straightforward, roles in pushing forward national and international action. ${ }^{8}$ Moreover, in this it also differs from the initial 'environment security' debates of the 1990s, in which natural and political scientists most famously Thomas Homer-Dixon and colleagues - played crucial roles, alongside journalists and policymakers, in redefining the environment as a key post-Cold War national security challenge.? By contrast with these areas, in the genealogy of climate security it is defence policy planners and their scenario reports which have been at the helm. Thus the first major climate security study, commissioned by the Pentagon's leading futurologist, contained very little evidence but nonetheless envisaged large-scale military confrontations over natural resources, a 'flood of refugees' arriving in the US from the Caribbean (by 2012!), and civil war in China plus the 'near collapse' of the EU (by 2025). ${ }^{10}$ Likewise, the single most influential report on the subject, a 2007 study authored by a dozen retired three- and four-star US generals and admirals, concluded that climate change will act as a threat multiplier for instability in some of the most volatile regions of the world' - though, once again, with only the thinnest of evidence bases. ${ }^{11}$ These and other early reports were primarily exercises in securitisation, oriented to pushing climate change up national security - and also diplomatic and development - agendas. Only in their wake has a significant body of actual research been produced on the subject. Any discourse always has multiple origins, of course, but climate security discourse has clearly been led and shaped more by policy actors than by scientific evidence.

This is not at all to suggest that climate security discourse is unchanging, or has remained uncontested. The quality of academic debate on climate security has certainly improved. Dozens of quantitative studies of climate-conflict linkages have now been published, with some finding clear evidence of linkages, and others reaching contrary conclusions. ${ }^{12}$ A number 
of excellent critiques of climate security thinking and its 'securitisation' of climate change have been produced..$^{13}$ Moreover, a fair number of analyses now stray from the Malthusian narrative outlined above, to include discussions of such themes as the conflict potential of geo-engineering and bio-fuels production, ${ }^{14}$ the potential for urban climate-related conflict, ${ }^{15}$ the impacts of violence in aggravating climate change vulnerabilities, ${ }^{16}$ and the possibility of climate change promoting peace-building. ${ }^{17}$ Reflecting this, the most recent Intergovernmental Panel on Climate Change (IPCC) assessment report's treatment of conflict and security issues constitutes a marked improvement on its earlier iterations. For while these earlier reports were evidentially slight, relentlessly Malthusian in their emphases, and also unrepresentative of the then state of knowledge on environment-security linkages ${ }^{18}$ the Fifth Assessment Report's (AR5's) treatment of conflict and security issues is arguably none of these things - instead referencing over 100 studies, and reviewing not only the Malthusian literatures on climate-induced 'collapse' and drought-conflict linkages in Africa, but also critiques of Malthusian thinking (especially representations of the 2003-2005 Darfur conflict as a 'climate war') plus several of the non-Malthusian themes noted above. ${ }^{19}$

Nonetheless, problems remain. Whatever the merits of AR5's detailed review of the climate security literature, its summary reverts to standard Malthusian tropes: 'livelihoods, culture, migration and conflict' are presented as the 'key elements' of the climate security problematique, with climate change portrayed as effecting a 'deterioration of livelihoods', and this in turn sparking migration, changes in cultural practices and - in the absence of functioning institutions - an increased risk of conflict. ${ }^{20}$ Moreover, public and policy discourse on climate security has barely changed. Like Ed Davey and many before him, the Pentagon now follows the Center for Naval Analysis (CNA) in characterising climate change as a 'threat multiplier' - one that will 'aggravate stressors abroad such as poverty, environmental degradation, political instability, and social tensions - conditions that can enable terrorist activity and other forms of violence'. ${ }^{21}$ Meanwhile, in its most recent report on the subject, the CNA claims that climate change impacts are 'already accelerating instability in vulnerable areas of the world and serving as catalysts for conflict' - despite offering barely a shred of supporting evidence. ${ }^{22}$ Climate security discourse is not nearly as monolithic as it once was, but further critical interrogation is still required.

\section{THE CONTRIBUTIONS TO THIS SPECIAL ISSUE}

This special issue presents a series of just such critical interrogations. Based on papers initially presented at the Rethinking Climate Change, Conflict and Security conference held at the University of Sussex, UK, in $2012,{ }^{23}$ plus other invited contributions, it is the first collection of its sort dedicated to 
problematising and going beyond contemporary climate security orthodoxies. For while some excellent critiques of climate security discourse have been produced in recent years, as noted above, none of these has been published within any of the high-profile special issues on the subject with the latter instead presenting quite mainstream, Malthusian and Africacentred analyses, even when they have sometimes concluded that there is not yet much evidence for climate change as an important driver of conflict'. ${ }^{24}$ By contrast, the articles that follow all diverge from orthodox Malthusian accounts of climate security. Instead, their common thread lies in their emphasis on the centrality of the political within the climate-conflict problematique, and in their arguments - whether explicitly made or not for a re-politicisation of climate security discourse.

The first four articles are essentially critiques of particular aspects of this mainstream thinking. To start with, the articles by Betsy Hartmann and Harry Verhoeven present complementary interrogations of climate security discourse as it pertains to the region most frequently associated with climate-driven chaos: Sub-Saharan Africa. Common to their approaches is an insistence on the importance of historicising contemporary climate security narratives - with Hartmann demonstrating how these are rooted in the conservative philosophy of Thomas Malthus, as well as in colonial ecology; and Verhoeven emphasising that representations of the African environment, whether of 'gardens of Eden' or 'hearts of darkness', have long been central to colonial and imperial imaginaries. By extension, both Hartmann and Verhoeven also argue that, like its various Malthusian predecessors, contemporary climate security discourse says more about Northern stereotypes, parables and fears than it does about Africa per se; and that this discourse has powerful political effects, constituting part of what Hartmann refers to as a new 'anticipatory regime for Africa' that functions as an ideal accomplice to local political restructuring as well as international intervention. Verhoeven specifically emphasises the central supporting roles played by African elites in climate and environmental security discourse, while Hartmann stresses its highly gendered character, especially in its convergence with international population initiatives. Together, these two articles raise key themes that recur throughout this special issue: climate security discourse's simplistic misreadings of human-environment relations; its historical debt to colonial and racialised narratives; its imbrication with power; its troubling political effects; and, not least, the need for forms of analyses that help to historicise and re-politicise our understanding of the conflict and security implications of climate change.

The next two articles offer more specific critiques, with Michael Mason exploring climate security discourse within a particular policy arena, and Jan Selby providing a methodology critique of large-N studies on climate change and conflict. Mason critiques human security readings of the climate security problematique - i.e., formulations which treat populations 
and individuals rather than the state as the referent objects of security - by analysing their deployment within United Nations vulnerability assessments in conflict and post-conflict areas. Focusing especially on the work of the UN Development Programme, the UN Environment Programme and the Office for the Coordination of Humanitarian Affairs, he argues that these agencies' climate vulnerability assessments apply a technical-managerial logic which leads them to downplay the effects of organised violence in producing environment-related insecurities, to obscure responsibility for conflict-related harms, and to promote depoliticised climate adaptation policies. Though not explicitly articulated in these terms, Mason's biopolitical analysis illustrates that the securitisation of climate change is not only problematic when done in the name of national security: human securitisations of climate change can have no less questionable effects.

By contrast with Mason's primarily policy-oriented focus, Selby's contribution critiques the dominant 'scientific' approach to understanding climate security, namely large-N quantitative studies of the relations between climatic and conflict variables. Exploring both their specific coding and causal practices, and their underlying epistemological premises, Selby argues that the correlations identified within these studies are spurious; that even if they were meaningful they would not provide a solid foundation for advancing predictions about the conflict impacts of climate change; and that, for all their pretensions to value-free scientific analysis, they reflect and reproduce the sort of conservative readings of future climate chaos identified by Hartmann and Verhoeven. Selby thus calls for a departure from positivistquantitative climate conflict research and, paralleling arguments made in the three preceding papers, for a re-politicisation of academic discourse on climate security.

In the middle of the special issue, Franziskus von Lucke, Zehra Wellmann and Thomas Diez present not so much a critique, as a new typology and out of that a set of normative questions for approaching the securitisation of climate change. Distinguishing between 'territorial'-, 'individual'- and 'planetary'-level securitisations, and between processes of 'securitisation' and 'riskification' - the former involving the discursive construction of existential threats that legitimate extraordinary measures, the latter diffuse and uncertain challenges which are instead linked to precautionary management - von Lucke et al. identify six distinct ways in which climate change has recently been securitised, and on this basis pose a series of questions about the political dangers associated with these different types. Though their answers to these questions are cautiously stated, von Lucke et al.'s premise is that the representation of climate change as a security problem is not a neutral or technical act, but a normative one that thus demands the exercise of ethico-political judgement.

The final three papers present new interpretations of actual and potential climate-conflict linkages which extend beyond Malthusian orthodoxy. 
Ayesha Siddiqi, first, offers a contextualised qualitative analysis of the impacts of a climatic disaster - the large-scale flooding that affected southern Pakistan in 2010-2011 - on local political militancy. Challenging the dominant narrative of Islamist militant groups mobilising and extending their power base on the back of this flooding, especially through rescue and relief activities, Siddiqi instead finds the political impacts of the floods to have been contradictory, uneven and context-dependent. In particular, she emphasises that both human agency and pre-existing political structures and dynamics - whether local patterns of social exclusion, or tacit alliances between local power brokers, state officials and militants - were decisive in shaping patterns of post-disaster Islamist mobilisation. By implication, Siddiqi's contribution highlights the centrality of political structures and action in determining whether and how climatic shocks and changes may - or may not - feed into patterns of conflict.

Janani Vivekananda, Janpeter Schilling and Dan Smith also explore community-level dynamics, in their case within three districts of post-conflict Nepal. By contrast with Malthusian studies, which emphasise the impacts of human-environment relations on conflict, Vivekananda et al. do the reverse, analysing the impacts of Nepal's protracted civil war and post-conflict instability on local vulnerability, adaptation and resilience to climate change. They find that local resilience across their three districts is principally constrained by 'bad governance and weak institutions', stemming mainly from Nepal's legacy of conflict, though also from conflicts over international aid, including climate change adaptation funding. Notwithstanding this, they argue that large-scale international aid, adaptation funding included, is vital to postconflict countries such as Nepal - and insist that the challenge is to develop 'holistic' approaches to resilience-building that are as sensitive to political and governance as to environmental factors. For all the differences between them, Vivekananda et al. thus share with Mason a common concern at the 'anti-political' character of contemporary climate change development interventions.

The final article, by Alexander Dunlap and James Fairhead, also explores adaptation-related conflicts, but in this case in relation to global political and political economic processes. Dunlap and Fairhead argue that international climate change adaptation and mitigation policies, and other associated global environmental policies, are already driving the creation of new commodities and markets for carbon, biofuels, biodiversity and food, and in turn are contributing worldwide to conflict-ridden transformations in access to land, forests and water. Using diverse examples, they demonstrate how the commodification and marketisation of nature has long been a violent, militarised process, and how recent extensions of this - through climate change-related conservation, offsetting and land acquisition programmes are themselves fomenting conflict. And they contend that the problem with mainstream climate security discourse is not just that it generally ignores 
these already-existing processes in favour of speculation about future threats, but that its securitisations are actively contributing to marketisation and militarisation in the global periphery.

Taken together, the contributions to this special issue highlight the inadequacy of Malthusian climate security thinking. They do this not by discounting the possibility of climate-related conflicts, but by emphasising that conflict is shaped principally by political forces - which are at once global and local, material and discursive, structured and agential - and which cannot be 'reduced to climate'. ${ }^{25}$ As several of our contributors emphasise, the securitisation of warming, droughts and floods is not only evidentially weak and unwarranted. It may also give succour to regressive political forces, or may become self-fulfilling, with discursive securitisation feeding and legitimating militarised policy responses. And it may end up doing very little - and may even obstruct or distract attention from - the huge challenge of decarbonising contemporary global society and actually stemming global anthropogenic climate change. It is hoped that the present articles make some contribution, however small, to forestalling these possibilities.

\section{NOTES}

1. E. Davey, Speech to Climate and Resource Security Dialogue for the 21st Century conference, Lancaster House, London, 22 March 2012, available at <https://www.gov.uk/government/speeches/ edward-davey-speech-to-climate-resource-security-dialogue-for-the-21st-century-conference>, accessed 26 Aug. 2014.

2. Quote drawn from the conference report, available at <https://www.wiltonpark.org.uk/wpcontent/uploads/wp1167-report.pdf>, accessed 26 Aug. 2014. The other claim, and the claims that follow, are drawn from Jan Selby's notes from the conference; given Chatham House rules, these claims cannot be attributed. See also the conference programme, available at $<$ https://www.wiltonpark.org.uk/wpcontent/uploads/wp1167-programme.pdf>, accessed 26 Aug. 2014.

3. Kurt Campbell, Jay Gulledge, J. R. McNeill, John Podesta, Peter Ogden, Leon Fuerth, R. James Woolsey, et al., The Age of Consequences: The Foreign Policy and National Security Implications of Global Climate Change (Washington, DC: Center for Strategic and International Studies/Center for a New American Security 2007) p. 8.

4. J. Zimmerer, 'Forward', International Journal of Human Rights 18/3 (2014) p. 263.

5. M. B. Burke, Edward Miguel, Shanker Satyanath, John A. Dykema, and David B. Lobell, 'Warming Increases the Risk of Civil War in Africa', Proceedings of the National Academy of Sciences 106/49 (2009) pp. 20670-20674.

6. Leon Fuerth, 'Security Implications of Climate Change 2: Severe Climate Change Over Next 30 Years', in Kurt Campbell, Jay Gulledge, J. R. McNeill, John Podesta, Peter Ogden, Leon Fuerth, R. James Woolsey, et al., The Age of Consequences: The Foreign Policy and National Security Implications of Global Climate Change (Washington DC: Center for Strategic and International Studies/Center for a New American Security 2007) pp. 71-79.

7. M. Hulme, 'Reducing the Future to Climate: A Story of Climate Determinism and Reductionism', Osiris 26/1 (2011) pp. 245-266.

8. See, e.g., M. Hulme, Why We Disagree About Climate Change: Understanding Controversy, Inaction and Opportunity (Cambridge: Cambridge University Press 2009) especially ch. 3; C. A. Miller and P. N. Edwards (eds.), Changing the Atmosphere: Expert Knowledge and Environmental Governance (Cambridge: MIT Press 2001); and P. Newell, Climate for Change: Non-State Actors and the Global Politics of the Greenhouse (Cambridge: Cambridge University Press 2000) ch. 3. 
9. See N. L. Peluso and M. Watts (eds.), Violent Environments (Ithaca: Cornell University Press 2001), especially the chapters by Peluso and Watts, 'Violent Environments', pp. 3-38, and B. Hartmann, 'Will the Circle Be Unbroken? A Critique of the Project on Environment, Population and Security', pp. 39-62. Homer-Dixon's key pieces are: 'On the Threshold: Environmental Changes as Causes of Acute Conflict', International Security 16/2 (1991) pp. 76-116; 'Environmental Scarcities and Violent Conflicts: Evidence From Cases', International Security 19/1 (1994) pp. 5-40; and Environment, Scarcity and Violence (Princeton: Princeton University Press 1999).

10. P. Schwarz and D. Randall, An Abrupt Climate Change Scenario and its Implications for United States National Security (Pasadena: California Institute of Technology 2003) especially p. 17, available at <http://oai.dtic.mil/oai/oai?verb=getRecord\&metadataPrefix=html\&identifier=ADA469325>, accessed 28 Aug. 2014.

11. CNA Military Advisory Board, National Security and the Threat of Climate Change (Alexandria: Centre for Naval Analysis Corporation 2007) p. 44.

12. See recent reviews of these quantitative studies by S. M. Hsiang and M. Burke, 'Climate, Conflict, and Social Stability: What Does the Evidence Say?', Climatic Change 123/1 (2013) pp. 39-55; J. Scheffran, M. Brzoska, J. Kominek, P. M. Link, and J. Schilling, 'Disentangling the Climate-Conflict Nexus: Empirical and Theoretical Assessment of Vulnerabilities and Pathways', Review of European Studies 4/5 (2012); and O. M. Theisen, N. P. Gleditsch, and H. Buhaug, 'Is Climate Change a Driver of Armed Conflict?', Climatic Change 117/3 (2013) pp. 613-625.

13. See, e.g. M. Carr, 'Slouching Towards Dystopia: The New Military Futurism', Race and Class 51/3 (2010) pp. 13-32; S. Dalby, Security and Environmental Change (Cambridge: Polity 2009); B. Hartmann, 'Rethinking Climate Refugees and Climate Conflict: Rhetoric, Reality, and the Politics of Policy Discourse', Journal of International Development 22/2 (2010) pp. 233-246; and B. Korf, 'The Imaginative Geographies of Climate Wars', Procedia: Social and Behavioural Sciences 14 (2011) pp. 35-39.

14. See, e.g., S. M. Borras, P. McMichael, and I. Scoones, 'The Politics of Biofuels, Land and Agrarian Change: Editors' Introduction', Journal of Peasant Studies $37 / 4$ (2010) pp. 575-592; S. Dalby, 'Climate Change: New Dimensions of Environmental Security', RUSI Journal 158/3 (2013) pp. 34-43; G. D. Dabelko, L. Herzer, S. Null, M. Parker, and R. Sticklor (eds.), Backdraft: The Conflict Potential of Climate Change Adaptation and Mitigation, Security Report 14/2 (Washington, DC: Woodrow Wilson Center Environmental Change for Scholars 2013); J. Fairhead, M. Leach, and I. Scoones, 'Green Grabbing: A New Appropriation of Nature?', Journal of Peasant Studies 39/2 (2012) pp. 237-261; and T. Molony and J. Smith, 'Biofuels, Food Security and Africa', African Affairs 109/436 (2010) pp. 489-498.

15. See, e.g., Dalby, 'Climate Change' (note 14).

16. See, e.g., W. N. Adger, 'Climate Change, Human Well-Being and Insecurity', New Political Economy 15/2 (2010) pp. 275-292; and S. Eriksen and J. Lind, 'Adaptation as a Political Process: Adjusting to Drought and Conflicts in Kenya's Drylands', Environmental Management 43/5 (2009) pp. 817-835.

17. See, e.g., D. Tänzler, A. Maas, and A. Carius, 'Climate Change Adaptation and Peace', Wiley Interdisciplinary Reviews: Climate Change 1/5 (2010) pp. 741-750.

18. On this see especially, R. Nordås and N. P. Gleditsch, 'Climate Change and Conflict', Political Geography 26/6 (2007) pp. 628-631; and R. Nordås and N. P. Gleditsch, 'IPCC and the Climate-Conflict Nexus', paper presented at the International Studies Association annual convention 2009.

19. C. B. Field, V. R. Barros, D. J. Dokken, K. J. Mach, M. D. Mastrandrea, T. E. Bilir, M. Chatterjee, et al. (eds.), Climate Change 2014: Impacts, Adaptation, and Vulnerability. Part A: Global and Sectoral Aspects. Contribution of Working Group II to the Fifth Assessment Report of the Intergovernmental Panel on Climate Change, Chapter 12 (Human Security), Final Draft, pp. 15-23, available at <http://ipcc-wg2. gov/AR5/images/uploads/WGIIAR5-Chap12_FGDall.pdf>, accessed 28 Aug. 2014.

20. Ibid. p. 22.

21. US Department of Defense, Quadrennial Defense Review 2014 (Washington, DC: DoD 2014) p. 8, available at <http://www.defense.gov/pubs/2014_Quadrennial_Defense_Review.pdf $>$, accessed 28 Aug. 2014.

22. CNA Military Advisory Board, National Security and the Accelerating Risks of Climate Change (Alexandria: Centre for Naval Analysis Corporation 2014) p. 2.

23. 'Rethinking Climate Change, Conflict and Security' conference, University of Sussex, UK, 18-19 Oct. 2012, programme available at <http://rethinkingclimateconflict.wordpress.com/>, accessed 26 Aug. 2014. This conference was supported by the EU Framework 7 project Climate Change, HydroConflicts and Human Security (CLICO), the Sussex Centre for International Security, and Sussex's School 
of Global Studies. The editors are grateful to them for having made this conference, and thus this special issue, possible.

24. N. P. Gleditsch, 'Whither the Weather? Climate Change and Conflict', Journal of Peace Research 49/1 (2012) p. 7. The special issues in question have been published in Political Geography 26/6 (2007); Journal of Peace Research 49/1 (2012); Climatic Change 123/1 (2013); and International Journal of Human Rights 18/3 (2014).

25. Hulme, 'Reducing the Future to Climate' (note 7). 